\title{
ASSOCIATION OF EDUCATIONAL, OCCUPATIONAL STATUS AND RELIGION WITH CONSANGUINITY
}

\author{
Sundip Hemant Charmode ${ }^{1}$
}

${ }^{1}$ Assistant Professor, Department of Anatomy, ESIC Medical College, Paravoor Road, Parippally, Kollam.

ABSTRACT
BACKGROUND
It is widely perceived that consanguinity is more prevalent among the underprivileged in the society. In general, consanguinity
is influenced by geographic, demographic, religious, cultural and socio-economic factors. Consanguineous marriage is widely
practiced in India particularly, in traditional Muslim communities and Hindu communities in South India. In present study, an
effort has been made to study the association between educational and occupational status of parents and their religion with the
occurrence of consanguineous marriages.

\section{AIM AND OBJECTIVES}

To determine the association of educational and occupational status of parents and their religion with occurrence of consanguineous marriages.

\section{MATERIALS AND METHODS}

The present study is subset of my previous study, which was done retrospectively in Government Medical College and Civil Hospitals of Western Maharashtra between 1 ${ }^{\text {st }}$ Oct. 2011 till 31 $1^{\text {st }}$ May 2012. A total of 182 congenitally defective live births and stillbirths admitted in above hospitals in same period were studied against total deliveries taken place. Information was collected by using questionnaires and pedigree charts were formed. Information about consanguinity, degree of consanguinity, parental education, parental occupation, religion, etc. was obtained. Data obtained was statistically analysed.

\section{RESULTS}

1. Incidence of congenital anomalies is $1.16 \%$.

2. Consanguineous marriages and offsprings with congenital defect are more common among parents who are educated up to primary and secondary education level.

3. Consanguineous marriages and offsprings with congenital defect are more common among parents of low socio-economic status, i.e. mothers who are housewives and fathers who are farmers.

4. Frequency of consanguineous marriage was found more in Muslims than Hindus.

\section{DISCUSSION AND CONCLUSION}

1. Incidence of congenital anomalies is $1.16 \%$.

2. Consanguineous marriages and offsprings with congenital defect are found to occur more commonly to parents with primary and secondary education.

3. Consanguineous marriages and offsprings with congenital defect occur more commonly to parents of low socio-economic status, i.e. mothers who are housewives and fathers who are farmers.

4. Frequency of consanguineous marriage is found more in Muslims than Hindus.

\section{KEYWORDS}

Consanguinity, Congenital Defect, Congenital Anomaly, Congenital Malformation, Consanguineous Marriage.

HOW TO CITE THIS ARTICLE: Charmode SH. Association of educational, occupational status and religion with consanguinity. J. Evolution Med. Dent. Sci. 2016;5(34):1939-1945, DOI: 10.14260/jemds/2016/458

\section{INTRODUCTION}

Consanguineous marriages are union between two people who share at least one recent common ancestor. ${ }^{1}$ In clinical genetics, a consanguineous marriage is commonly defined as union between subjects related as second cousin or closer, equivalent to an inbreeding coefficient in their progeny of $\mathrm{F} \geq$ $0.0156 .^{2}$ It is widely perceived that consanguinity is more prevalent among the underprivileged in the society. ${ }^{3-5}$ In general, consanguinity is influenced by geographic, demographic, religious, cultural and socio-economic factors. ${ }^{6}$

Financial or Other, Competing Interest: None.

Submission 09-03-2016, Peer Review 04-04-2016,

Acceptance 11-04-2016, Published 28-04-2016.

Corresponding Author:

Dr. Sundip Hemant Charmode,

ESIC Medical College,

Paravoor Road, Parippally,

Kollam-691574.

E-mail: sundip.charmode@yahoo.com

DOI: $10.14260 /$ jemds/2016/458
The highest rate of consanguineous unions is associated with low socio-economic status, low education and living in rural areas.5,7-11 India is composed of thousands of subpopulations divided by geography, language, religion and caste or boundaries. ${ }^{12}$

Consanguineous marriage is widely practiced here and reasons given are geographic, settling economic or inheritance problems, prospective mates knowing each other well, he (or she) is the only possible mate. ${ }^{13}$

From a genetic perspective, consanguineous marriage increases the chances that both members of the union will carry recessive variants passed through the family, which increases the chance that their offspring will be affected by a recessive disease. ${ }^{2}$

Consanguineous marriage is widely practiced in India, particularly in traditional Muslim communities and Hindu communities in South India. ${ }^{14-15}$

In my previous study, it was clearly observed that increased frequency of offsprings with congenital defect were 
born to consanguineous couples. In present study, an effort has been made to study the association between educational and occupational status of parents and their religion with the occurrence of consanguineous marriages.

\section{MATERIALS AND METHODS}

The present study is subset of my previous study, which is retrospective in nature and conducted in Government Medical College and Hospital in Western Maharashtra. Before starting the study, prior permission of Professor and Head of Department of Anatomy, Obstetrics and Gynaecology and Paediatrics of college mentioned above was taken. Approval of Ethical Committee was also acquired.

182 new births with congenital defect of any system of human body born in or referred to the above hospitals including stillbirths and abortions during the period between 1st October 2011 and 31st May 2012 were included in the study.

At the time of birth or referral the outcome of conception, i.e. abortion, intrauterine death, live birth, neonatal death, stillbirth with any congenital malformation was termed as Proband. 16

Before taking the history, informed consent of parents of proband was taken using the consent form and the information was kept confidential.

Patient's history was recorded using the proforma/questionnaire, especially designed for the study in Marathi and English by meeting the parents of proband in person. Proband whose history was insufficient and in which the follow-up of parents could not be done were removed from the study.

The proforma/questionnaire for history taking included detailed information regarding type of congenital defect, history of consanguineous relationship between the parents and degree of consanguinity, education and occupation of both the parents, religion of parents. Pedigree charts were prepared in all the cases.

All the probands studied were compared with respect to their parental education, occupation, religion, presence of consanguineous relationship in parents and degree of consanguinity and accordingly classification of probands was done.

For classification according to parental education, five categories of parental education were created as illiterate, i.e. having none/zero years of education; primary and secondary education, i.e. between 0 to 8 yrs. after age of 5 years; SSC passed, i.e. between 9-10 yrs. of education; HSC passed, i.e. between 11-12 yrs. of education; and graduate and above, i.e. beyond 13 yrs. of education (S. Harlap et al study). ${ }^{17}$

For classification according to parental occupation, three categories of paternal occupation were created as Unemployed, Farming and Employed; in maternal occupation categories were housewife, farming and employed. For religion, Hindu and Muslim were two categories.

Data collected has been tabulated and shown by using bar diagrams and pie chart.

The findings were then statistically analysed using Pearson chi-square test and "p value" determined. Statistical significance of each finding was mentioned below each table, which were then discussed with other comparable studies done previously by authors within or outside India and final conclusions were drawn from the present study.

\section{OBSERVATIONS AND RESULTS}

It is found that in the period between $1{ }^{\text {st }}$ October 2011 and 31 st May 2012, total deliveries taking place in Government Medical College and both civil hospitals were 10,114 including (Normal and caesarean section) and total admissions of anomalous births in the NICU were 182, hence incidence of congenital defects calculated is $1.79 \%$.

\begin{tabular}{|c|c|c|c|c|}
\hline \multirow{4}{*}{} & & \multicolumn{2}{|c|}{ Consanguinity } & \multirow{2}{*}{ Total } \\
\cline { 2 - 5 } & $\begin{array}{c}\text { Category of } \\
\text { Education }\end{array}$ & Yes & No & \\
\hline \multirow{4}{*}{$\begin{array}{c}\text { Maternal } \\
\text { education }\end{array}$} & Illiterate & 3 & 26 & 29 \\
\cline { 2 - 5 } & $\begin{array}{c}\text { Primary \& } \\
\text { secondary }\end{array}$ & 23 & 48 & 71 \\
\cline { 2 - 5 } & SSC & 6 & 20 & 26 \\
\cline { 2 - 5 } & HSC & 6 & 13 & 19 \\
\cline { 2 - 5 } & $\begin{array}{c}\text { Graduate \& } \\
\text { above }\end{array}$ & 10 & 27 & 37 \\
\hline \multicolumn{2}{|c|}{ Total } & \multicolumn{4}{|c|}{$\mathbf{4 8}$} & $\mathbf{1 3 4}$ & $\mathbf{1 8 2}$ \\
\hline \multicolumn{2}{|c|}{ Table 1: Maternal Education and Consanguinity } \\
\hline
\end{tabular}

In Table 1.17 maternal education and occurrence of consanguineous cases are compared and it shows that out of all 182 cases, 71 cases belonged to mother who are primary and secondary level educated, which is $39.01 \%$.

Also in consanguineously related couples, i.e. 48 cases of all 182 cases, largest cases 23 cases belonged to primary and secondary education level group which are $47.91 \%$.

\begin{tabular}{|c|c|c|c|c|}
\hline & \multirow{2}{*}{$\begin{array}{l}\text { Category of } \\
\text { Education }\end{array}$} & \multicolumn{2}{|c|}{ Consanguinity } & \multirow[t]{2}{*}{ Total } \\
\hline & & Yes & No & \\
\hline \multirow{5}{*}{$\begin{array}{c}\text { Paternal } \\
\text { education }\end{array}$} & Illiterate & 5 & 16 & 21 \\
\hline & $\begin{array}{l}\text { Primary \& } \\
\text { secondary }\end{array}$ & 13 & 34 & 47 \\
\hline & SSC & 7 & 31 & 38 \\
\hline & HSC & 11 & 27 & 38 \\
\hline & $\begin{array}{c}\text { Graduate \& } \\
\text { above }\end{array}$ & 12 & 26 & 38 \\
\hline Total & & 48 & 134 & 182 \\
\hline \multicolumn{5}{|c|}{ Table 2: Paternal Education and Consanguinity } \\
\hline
\end{tabular}

Table 2 shows correlation between Paternal education and occurrence of consanguineous cases, which shows highest no. of cases, 47 out of 182 total cases studied belonged to primary and secondary level educated fathers which is $20.87 \%$.

Table 2 also shows that among the consanguineous cases (48 cases), highest no. of cases 13 out of 48 total consanguineous cases were born to fathers who were primary and secondary level educated which is $27.08 \%$ followed by graduate and above group and HSC educated group which is $25 \%$ and $22.9 \%$ respectively.

\begin{tabular}{|c|c|c|c|c|}
\hline \multirow{2}{*}{$\begin{array}{c}\text { Maternal } \\
\text { occupation }\end{array}$} & $\begin{array}{c}\text { Category of } \\
\text { Occupation }\end{array}$ & \multicolumn{2}{|c|}{ Consanguinity } & Total \\
\cline { 3 - 5 } & Housewife & 38 & 114 & 152 \\
\cline { 2 - 5 } & $\begin{array}{c}\text { Farmer } \\
\text { (Self-employed) }\end{array}$ & 5 & 2 & 7 \\
\cline { 2 - 5 } & Employed & 5 & 18 & 23 \\
\hline Total & & $\mathbf{4 8}$ & $\mathbf{1 3 4}$ & $\mathbf{1 8 2}$ \\
\hline \multicolumn{2}{|c|}{ Table 3: Maternal Occupation and Consanguinity } \\
\hline
\end{tabular}


Table 3 shows correlation of maternal occupation and consanguinity revealing that out of the 48 consanguineously married cases, highest 38 cases belonged to mothers who were housewives $79.16 \%$.

\begin{tabular}{|c|c|c|c|c|}
\hline & \multirow{2}{*}{$\begin{array}{l}\text { Category of } \\
\text { Occupation }\end{array}$} & \multicolumn{2}{|c|}{ Consanguinity } & \multirow[t]{2}{*}{ Total } \\
\hline & & Yes & No & \\
\hline \multirow[t]{3}{*}{$\begin{array}{c}\text { Paternal } \\
\text { occupation }\end{array}$} & $\begin{array}{c}\text { Farmer } \\
\text { (Self-employed) }\end{array}$ & 21 & 96 & 117 \\
\hline & Employed & 27 & 37 & 64 \\
\hline & Unemployed & 0 & 1 & 1 \\
\hline Total & & 48 & 134 & 182 \\
\hline
\end{tabular}

Table 4 shows correlation of Paternal occupation and consanguinity revealing that out of the 48 consanguineously married cases highest 27 cases belonged to fathers who are employed $56.25 \%$ followed by 21 cases who are farmers $43.75 \%$

\begin{tabular}{|c|c|c|c|c|}
\hline \multirow{2}{*}{} & \multirow{2}{*}{$\begin{array}{c}\text { Category } \\
\text { of } \\
\text { Religion }\end{array}$} & \multicolumn{2}{|c|}{ Non-Consanguinity } & \multirow{2}{*}{ Total } \\
\cline { 3 - 4 } & Yes & No & \\
\hline Religion & Hindu & 125 & 40 & 165 \\
\cline { 2 - 5 } & Muslim & 9 & 8 & 17 \\
\hline Total & \multicolumn{4}{|c|}{ Table 5: Religion and Consanguinity } \\
\hline \multicolumn{4}{|c}{} \\
\hline
\end{tabular}

Table 5 shows correlation between religion and consanguinity, which shows that in Muslim cases (17 cases) 8 are born to consanguineously married parents which is $47.05 \%$ than Hindus in which it is 40 out of 165 cases, i.e. $24.24 \%$. It shows that out of total 182 cases, Muslim cases are 17 cases and Hindu cases were 165.

Hence, frequency of consanguineous marriages is more in Muslims than Hindus.

\section{DISCUSSION}

Births with congenital defect are commonly found to occur among and the incidence calculated is $1.79 \%$ in the present study.

\section{Comparison between Maternal Education and Occurrence of Consanguineous Marriages}

\begin{tabular}{|c|c|c|c|c|c|c|c|c|c|c|}
\hline \multirow{3}{*}{$\begin{array}{c}\text { Maternal } \\
\text { Education in } \\
\text { Groups } \\
\text { Formed } \\
\text { According to } \\
\text { Present } \\
\text { Study }\end{array}$} & \multirow{2}{*}{\multicolumn{2}{|c|}{$\begin{array}{c}\text { No. of } \\
\text { Anomalous } \\
\text { Cases } \\
\text { Present } \\
\text { Study }\end{array}$}} & \multirow{3}{*}{$\begin{array}{l}\text { Percent } \\
\text { age } \\
\text { Present } \\
\text { Study }\end{array}$} & \multirow{3}{*}{$\begin{array}{c}\text { Acc. to } \\
\text { Groups of } \\
\text { Education } \\
\text { Hussian R } \\
\text { and } \\
\text { Bittles.19 } \\
\end{array}$} & \multicolumn{3}{|c|}{$\begin{array}{c}\text { PDHS (n=5533), Hussian R } \\
\text { and Bittles. }{ }^{18} \text { Study }\end{array}$} & \multicolumn{3}{|c|}{$\begin{array}{c}\text { NFHS (n =7965), Hussian R } \\
\text { and Bittles. }{ }^{18} \text { Study }\end{array}$} \\
\hline & & & & & \multirow[t]{2}{*}{ No } & \multirow[t]{2}{*}{$\begin{array}{l}\text { Unrelate } \\
\quad \text { d }\end{array}$} & \multirow[t]{2}{*}{$\begin{array}{c}\text { First } \\
\text { Cousin } \\
\quad s\end{array}$} & \multirow[t]{2}{*}{ No } & \multirow[t]{2}{*}{$\begin{array}{c}\text { Unrelate } \\
\text { d }\end{array}$} & \multirow[t]{2}{*}{$\begin{array}{c}\text { First } \\
\text { Cousin } \\
\quad s\end{array}$} \\
\hline & Con & $\begin{array}{c}\text { N- } \\
\text { Con }\end{array}$ & & & & & & & & \\
\hline Illiterate & 3 & 26 & 15.9 & $\begin{array}{c}\text { No } \\
\text { education }\end{array}$ & 4420 & 4.5 & 4.1 & 5234 & 4.1 & 4.0 \\
\hline \multirow{4}{*}{$\begin{array}{l}\text { Primary \& } \\
\text { secondary } \\
\text { education }\end{array}$} & \multirow{4}{*}{23} & \multirow{4}{*}{48} & \multirow{4}{*}{39.0} & Primary & 474 & 3.6 & 3.9 & 1214 & 3.6 & 3.7 \\
\hline & & & & Secondary & 584 & 3.2 & 3.1 & 1295 & 2.4 & 2.8 \\
\hline & & & & Total & 1058 & 6.8 & 7.0 & 2509 & 6.0 & 6.5 \\
\hline & & & & Percentage & $19.12 \%$ & & & $\begin{array}{c}31.5 \\
\%\end{array}$ & & \\
\hline SSC & 6 & 20 & 14.3 & Tertiary & 55 & 2.2 & 2.6 & 222 & 2.2 & 2.2 \\
\hline HSC & 6 & 13 & 10.4 & & & & & & & \\
\hline $\begin{array}{l}\text { Graduate \& } \\
\text { above }\end{array}$ & 10 & 27 & 20.3 & & & & & & & \\
\hline \multirow{2}{*}{$\begin{array}{c}\text { Total cases in } \\
\text { present } \\
\text { study }\end{array}$} & 48 & 134 & 100.0 & & & & & & & \\
\hline & \multicolumn{2}{|c|}{182} & & & & & & & & \\
\hline & & & & & e 6 & & & & & \\
\hline
\end{tabular}

In Table 6 Hussain R and Bittles A.H.18 in 2004 in their study from the PDHS and NFHS data showed that women married to first cousins were less likely to have undertaken post secondary education. Hence, proved that consanguinity was associated with low maternal education. This finding matches with that of present study.

In present study out of 182 cases, in 48 consanguineous cases highest number of cases belonged to mother who is primary and secondary level educated (23 cases), which is $47.9 \%$.

Harlap S et $\mathrm{al}^{17}$ in 2008, Hussain $\mathrm{R}$ et al ${ }^{18}$ in 2004, Carnilla Stolenberg et $\mathrm{al}^{19}$ in 1997, Khlat M, Khoury M.20 in 1991, Emma Kerkeni, Monastiri K. ${ }^{21}$ in 2006, Khalid Yunis MD et $\mathrm{al}^{22}$ in 2008 stated similar finding in their respective studies, that prevalence of consanguinous marriages is more common in lower maternal educational groups.

In Table 7, Emma Kerkeni et al $^{21}$ in 2006 in their study done found that $26.5 \%$ and $24.6 \%$ of consanguineous women were having less than primary education and primary education respectively. This finding matches with that of present study.

In the present study out of 182 cases, in 48 consanguineous cases, highest number of cases belonged to mother who was primary and secondary level educated (23 cases), which are $47.9 \%$ cases. 


\begin{tabular}{|c|c|c|c|c|c|c|c|c|c|}
\hline \multirow{4}{*}{$\begin{array}{c}\text { Maternal } \\
\text { Education Level }\end{array}$} & \multirow{2}{*}{\multicolumn{3}{|c|}{\begin{tabular}{|l|} 
Present Study \\
Consanguinity \\
\end{tabular}}} & \multicolumn{6}{|c|}{ Total Students Studied in Tunisia $(n=1016)$ Emma Kerkeni et al ${ }^{21}$ Study } \\
\hline & & & & \multirow{2}{*}{\multicolumn{2}{|c|}{$\begin{array}{l}\text { Consanguineous Men } \\
\text { (204) } 20.0 \%\end{array}$}} & \multirow{3}{*}{$\begin{array}{l}\text { Non-Con } \\
(\mathbf{8 1 2})\end{array}$} & \multirow{2}{*}{\multicolumn{2}{|c|}{$\begin{array}{l}\text { Consanguineous Women } \\
\text { (204) } 20.0 \%\end{array}$}} & \multirow{3}{*}{$\begin{array}{c}\text { Non- } \\
\text { Con } \\
(812)\end{array}$} \\
\hline & Yes & No & Total & & & & & & \\
\hline & & & & Cases & $\begin{array}{c}\text { \% Out of all Cases of } \\
\text { that Category and } \\
\text { Sex }\end{array}$ & & Cases & $\begin{array}{c}\text { \% Out of all Cases of } \\
\text { that Category and } \\
\text { Sex }\end{array}$ & \\
\hline Less than primary & 3 & 26 & 29 & 15 & 20.5 & & 48 & 26.5 & \\
\hline $\begin{array}{c}\text { Completed } \\
\text { primary school }\end{array}$ & \multirow{2}{*}{23} & \multirow{2}{*}{48} & \multirow{2}{*}{71} & 30 & 24.4 & & 56 & 24.6 & \\
\hline $\begin{array}{c}\text { Completed } \\
\text { secondary school }\end{array}$ & & & & 93 & 21.8 & & 76 & 18.1 & \\
\hline $\begin{array}{l}\text { Completed high } \\
\text { school and above }\end{array}$ & 22 & 60 & 82 & 66 & 16.8 & & 24 & 12.8 & \\
\hline Total & 48 & 134 & 182 & 204 & 100 & 812 & 204 & 100 & 812 \\
\hline \multicolumn{10}{|c|}{ Table 7} \\
\hline
\end{tabular}

\begin{tabular}{|c|c|c|c|c|c|c|c|c|}
\hline \multirow{2}{*}{$\begin{array}{l}\text { Education of } \\
\text { Mother in yrs. }\end{array}$} & \multirow{2}{*}{$\begin{array}{c}\begin{array}{c}\text { Total Births } \\
100 \%\end{array} \\
\begin{array}{c}\text { S. Harlap.18 } \\
\text { Study }\end{array} \\
\end{array}$} & \multicolumn{3}{|c|}{$\begin{array}{l}\text { Offsprings in \% whose Parents are } \\
\text { Consanguineously Related }\end{array}$} & \multirow[t]{2}{*}{$\begin{array}{c}\text { Education of } \\
\text { Mother in } \\
\text { Present Study }\end{array}$} & \multicolumn{3}{|c|}{ Consanguinity } \\
\hline & & $\begin{array}{c}\text { Any } \\
\text { Known }\end{array}$ & $\begin{array}{l}\text { Distant } \\
\text { Relation }\end{array}$ & $\begin{array}{c}\text { First } \\
\text { Cousin }\end{array}$ & & Yes & & Jo \\
\hline Unknown & 2882 & 16.1 & 8.1 & 7.6 & \multicolumn{2}{|l|}{ Illiterate } & 3 & 26 \\
\hline $0-4$ & 4903 & 18.1 & 8.9 & 8.9 & \multicolumn{2}{|c|}{$\begin{array}{c}\text { Primary and secondary } \\
\text { education }\end{array}$} & 23 & 48 \\
\hline $5-8$ & 10036 & 11.1 & 6.0 & 4.8 & \multicolumn{2}{|l|}{ SSC } & 6 & 20 \\
\hline $9-12$ & 8366 & 5.5 & 2.8 & 2.5 & \multicolumn{2}{|l|}{ HSC } & 6 & 13 \\
\hline $13+$ & 3628 & 2.6 & 1.7 & 0.9 & \multicolumn{2}{|c|}{ Graduate and above } & 10 & 27 \\
\hline Total & 29815 & & & & \multicolumn{2}{|l|}{ Total } & 48 & 134 \\
\hline
\end{tabular}

In Table 8, Harlap S. ${ }^{17}$ in 2008 in his study done in 1053 major birth defects in 29,815 total births born in 1964-76. He found that among the live births born to consanguineously married parents, highest number of mothers of these offsprings were having education of less than 8 yrs. This finding matches with that of present study.

In the present study out of 182 cases, in 48 consanguineous cases highest number of cases belonged to mother who was primary and secondary level educated $(23$ cases), which are $47.9 \%$ cases.

Comparison between Paternal Education and Occurrence of Consanguineous Marriages

In the present study, it shows that highest no. of cases 13 cases of all 48 cases of consanguineous marriages were born to primary and secondary level educated fathers.
Carnilla Stolenberg et al ${ }^{19}$ in Norway, Emma Kerkeni, Monastiri K.21 in 2006, Khlat M, Khoury M.20 in 1991, Harlap S, K. Klienhaus. ${ }^{17}$ in 2008 in their study stated similar finding that prevalence of consanguinous marriage is more common in lower educational groups and confirmed the association of major birth defects with parental consanguinity.

In Table 9, Emma Kerkeni, Monastiri K et al ${ }^{21}$ in 2006 in their study done in Tunisian students found that fathers with higher education level had lowest prevalence of consanguinity, but these findings were not statistically significant.

Emma Kerkeni, Monastiri $\mathrm{K}$ et $\mathrm{al}^{21}$ in 2006 in their study done found $20.5 \%, 24.4 \%$ and $21.8 \%$ of consanguineous men were having less than primary education and primary education and secondary education respectively.

\begin{tabular}{|c|c|c|c|c|c|c|c|c|c|}
\hline \multirow{4}{*}{$\begin{array}{c}\text { Paternal } \\
\text { Education Level }\end{array}$} & \multirow{2}{*}{\multicolumn{3}{|c|}{$\begin{array}{l}\text { Present Study } \\
\text { Consanguinity }\end{array}$}} & \multicolumn{6}{|c|}{ Total Students Studied in Tunisia (N=1016) Emma Kerkeni et al ${ }^{21}$ Study } \\
\hline & & & & \multirow{2}{*}{\multicolumn{2}{|c|}{$\begin{array}{l}\text { Consanguineous Men } \\
\text { (204) } 20.0 \%\end{array}$}} & \multirow{3}{*}{$\begin{array}{l}\text { Non- } \\
\text { Consan } \\
\text { (812) }\end{array}$} & \multirow{2}{*}{\multicolumn{2}{|c|}{$\begin{array}{c}\text { Consanguineous Women } \\
\text { (204) } 20.0 \%\end{array}$}} & \multirow{3}{*}{$\begin{array}{c}\text { Non- } \\
\text { Consan } \\
\text { (812) }\end{array}$} \\
\hline & \multirow[t]{2}{*}{ Yes } & \multirow[t]{2}{*}{ No } & \multirow[t]{2}{*}{ Total } & & & & & & \\
\hline & & & & Cases & $\begin{array}{c}\% \text { Out of all Cases } \\
\text { of that Category } \\
\text { and Sex }\end{array}$ & & Cases & $\begin{array}{c}\% \text { Out of all Cases } \\
\text { of that Category } \\
\text { and Sex }\end{array}$ & \\
\hline $\begin{array}{c}\text { Less than } \\
\text { primary }\end{array}$ & 5 & 16 & 21 & 15 & 20.5 & & 48 & 26.5 & \\
\hline $\begin{array}{c}\text { Completed } \\
\text { primary school }\end{array}$ & 13 & 34 & 47 & 30 & 24.4 & & 56 & 24.6 & \\
\hline $\begin{array}{c}\text { Completed } \\
\text { secondary school }\end{array}$ & & & & 93 & 21.8 & & 76 & 18.1 & \\
\hline $\begin{array}{l}\text { Completed high } \\
\text { school and above }\end{array}$ & 40 & 84 & 114 & 66 & 16.8 & & 24 & 12.8 & \\
\hline Total & 48 & 134 & 182 & 204 & 100 & 812 & 204 & 100 & 812 \\
\hline & & & & & Table 9 & & & & \\
\hline
\end{tabular}




\begin{tabular}{|c|c|c|c|c|c|c|c|c|c|c|c|}
\hline \multirow{3}{*}{$\begin{array}{c}\text { Maternal } \\
\text { Occupation }\end{array}$} & \multicolumn{6}{|c|}{$\begin{array}{c}\text { Total Students Studied in Tunisia }(n=1016) \\
\text { Emma Kerkeni et al }{ }^{21} \text { Study }\end{array}$} & \multirow[t]{3}{*}{$\begin{array}{c}\text { Occupation } \\
\text { Present } \\
\text { Study } \\
\end{array}$} & \multicolumn{4}{|c|}{$\begin{array}{l}\text { Consanguinity } \\
\text { Present Study }\end{array}$} \\
\hline & \multicolumn{2}{|c|}{$\begin{array}{c}\text { Consanguineous } \\
\text { Men (204) } \\
20.0 \% \\
\end{array}$} & \multirow[b]{2}{*}{$\begin{array}{l}\text { Non- } \\
\text { consan } \\
(812)\end{array}$} & \multicolumn{2}{|c|}{$\begin{array}{c}\text { Consanguineous } \\
\text { Women (204) } \\
20.0 \% \\
\end{array}$} & \multirow[b]{2}{*}{$\begin{array}{c}\text { Non-consan } \\
(812)\end{array}$} & & \multirow[b]{2}{*}{ Yes } & \multirow[b]{2}{*}{ No } & \multirow[b]{2}{*}{ Total } & \multirow[b]{2}{*}{$\%$} \\
\hline & Cases & $\begin{array}{l}\% \text { Out of } \\
\text { all cases } \\
\text { of that } \\
\text { category } \\
\text { and sex }\end{array}$ & & Cases & $\begin{array}{l}\% \text { Out of } \\
\text { all cases } \\
\text { of that } \\
\text { category } \\
\text { and sex }\end{array}$ & & & & & & \\
\hline Professional & 49 & 16.8 & & 30 & 14.0 & & \multirow{2}{*}{ Employed } & \multirow{2}{*}{5} & \multirow{2}{*}{18} & \multirow{2}{*}{23} & \multirow{2}{*}{12.6} \\
\hline Clerical & 36 & 19.9 & & - & - & & & & & & \\
\hline Housewives & - & - & & 163 & 23.8 & & Housewives & 38 & 114 & 152 & 83.5 \\
\hline $\begin{array}{l}\text { Agriculture, } \\
\text { laborers }\end{array}$ & 119 & 21.9 & & 11 & 8.8 & & $\begin{array}{l}\text { Farmer (Self- } \\
\text { employed) }\end{array}$ & 5 & 2 & 7 & 3.8 \\
\hline Total & 204 & 100 & 812 & 204 & 100 & 812 & Total & 48 & 134 & 182 & \\
\hline \multicolumn{12}{|c|}{ Table 10} \\
\hline
\end{tabular}

Table 10 shows Emma Kerkeni, Monastiri K.21 in 2006 in their study done in Tunisian students found that among all consanguineously married women, $23.8 \%$ i.e. 163 cases were born to mothers who were housewives. Hence, in Tunisia for women a strong trend of increasing prevalence of consanguinity with decreasing occupational status was seen. This finding is statistically significant.

In the present study, similar findings were stated that out of the 48 consanguineously married cases, highest 38 cases belonged to mothers who were Housewives i.e. 79.16\%. Also that in 152 cases, out of total 182 cases i.e. 83.5\% of total cases was born to mothers who were Housewives.

\section{Comparison of Paternal Occupation and Occurrence of Consanguineous Marriages}

In the present study, comparison of paternal occupation with occurrence of consanguineous marriages and anomalies was done and found that 117 cases out of total 182 cases, i.e. $64.3 \%$ of total cases were born to fathers with Farming as occupation. But out of the 48 consanguineously married cases, highest 27 cases belonged to fathers who were employed, i.e. $56.25 \%$ followed by 21 cases who were farmers $43.75 \%$. Hence, no significant trend was seen from the findings.

Emma Kerkeni, Monastiri K.21 in 2006 in their study done in Tunisian students stated similar finding that for men highest occupational status/professionals showed the lowest prevalence of consanguinity. Shown in Table 11 below.

This finding was not statistically significant. But this finding does not match with that of present study.

\begin{tabular}{|c|c|c|c|c|c|c|c|c|c|c|c|}
\hline \multirow{3}{*}{$\begin{array}{c}\text { Paternal } \\
\text { Occupation }\end{array}$} & \multicolumn{6}{|c|}{$\begin{array}{l}\text { Total Students Studied in Tunisia }(\mathrm{N}=1016) \\
\text { Emma Kerkeni et al }{ }^{21} \text { Study }\end{array}$} & \multirow[t]{3}{*}{$\begin{array}{l}\text { Occupation } \\
\text { Present } \\
\text { Study } \\
\end{array}$} & \multicolumn{4}{|c|}{ Consanguinity } \\
\hline & \multicolumn{2}{|c|}{$\begin{array}{c}\text { Consanguineous } \\
\text { Men (204) } \\
20.0 \%\end{array}$} & \multirow{2}{*}{$\begin{array}{l}\text { Non- } \\
\text { consan } \\
(812)\end{array}$} & \multicolumn{2}{|c|}{$\begin{array}{c}\text { Consanguineous } \\
\text { Women (204) } \\
20.0 \%\end{array}$} & \multirow{2}{*}{$\begin{array}{c}\text { Non- } \\
\text { consan } \\
(812)\end{array}$} & & \multirow[b]{2}{*}{ Yes } & \multirow[b]{2}{*}{ No } & \multirow[b]{2}{*}{ Total } & \multirow[b]{2}{*}{$\%$} \\
\hline & Cases & $\begin{array}{l}\% \text { Out of } \\
\text { all Cases } \\
\text { of that } \\
\text { Category } \\
\text { and Sex }\end{array}$ & & Cases & $\begin{array}{l}\% \text { Out of } \\
\text { all Cases } \\
\text { of that } \\
\text { Category } \\
\text { and Sex }\end{array}$ & & & & & & \\
\hline Professional & 49 & 16.8 & & 30 & 14.0 & & \multirow{2}{*}{ Employed } & \multirow{2}{*}{27} & \multirow{2}{*}{37} & \multirow{2}{*}{64} & \multirow{2}{*}{35.2} \\
\hline Clerical & 36 & 19.9 & & - & - & & & & & & \\
\hline Housewives & - & - & & 163 & 23.8 & & Unemployed & 0 & 1 & 1 & 0.5 \\
\hline $\begin{array}{c}\text { Agriculture, } \\
\text { laborers }\end{array}$ & 119 & 21.9 & & 11 & 8.8 & & Farmer & 21 & 96 & 117 & 64.3 \\
\hline Total & 204 & 100 & 812 & 204 & 100 & 812 & Total & 48 & 134 & 182 & \\
\hline
\end{tabular}

Table 11 shows Emma Kerkeni, Monastiri K.21 in 2006 in their study found that for men, out of all 204 consanguineously married fathers, highest no. of cases, i.e. 119 cases were born to fathers with occupation of agricultural type, i.e. Farming group. But this finding was not statistically significant.
In the present study out of the 48 consanguineously married cases, highest 27 cases belonged to fathers who were employed, i.e. $56.25 \%$, i.e. professionals and labourers combined group as in present study and not farming group. This could have occurred as in present study; in farmer group laborers were not included which were instead included in employed group. Exactly reverse was done in Emma Kerkeni et $\mathrm{al}^{22}$ study. 
Comparison of Religion and Occurrence of Consanguineous Marriages

In present study out of all 182 anomalous cases studied, 48 cases were consanguineous, i.e. 26.4\%. 165 cases were Hindus and 17 cases were Muslims. Muslims had a higher frequency $(47.5 \%)$ of consanguineous marriages than Hindus (24.24\%). However, this difference in the frequency was not statistically significant.
A. Nath et al ${ }^{23}$ in 2004 , Harlap S et al ${ }^{17}$ in 2008, Hussain $\mathrm{R}$ et $\mathrm{al}^{18}$ in 2004 , Khalid Yunis MD et $\mathrm{al}^{22}$ in 2008 in their respective studies have stated that consanguinous marriages were more common in Muslims than Hindus. This finding matches with present study.

Asha Bai P V, John T I et al24 in 1981 in their study stated that consanguinity is more prevalent in Hindus than Muslims. This finding differs with present study finding.

\begin{tabular}{|c|c|c|c|c|c|c|c|c|c|}
\hline \multirow{3}{*}{$\begin{array}{c}\text { Religion } \\
\text { A. Nath, C } \\
\text { Patil } \\
\text { et al24 } \\
\text { Study }\end{array}$} & \multicolumn{4}{|c|}{$\begin{array}{c}\text { Total Cases Studied, } n=500,100 \% \text {, } \\
\text { A. Nath et al }{ }^{23} \text { Study }\end{array}$} & \multicolumn{4}{|c|}{$\begin{array}{c}\text { Total Anomalous Cases Studied, } n=182 \text {, } \\
100 \% \text {, in Present Study }\end{array}$} & \\
\hline & \multicolumn{2}{|c|}{$\begin{array}{l}\text { Non-Consanguineous } \\
\text { Unions }=320,64 \% \text { A. } \\
\text { Nath, C Patil. }{ }^{23} \text { Study }\end{array}$} & \multicolumn{2}{|c|}{$\begin{array}{c}\text { Consanguineous } \\
\text { Unions }=180,36 \% \\
\text { A. Nath, C Patil.23 Study }\end{array}$} & \multicolumn{2}{|c|}{$\begin{array}{c}\text { Non-Consanguineous } \\
\text { Cases n=134 } \\
\text { \% In Present Study }\end{array}$} & \multicolumn{2}{|c|}{$\begin{array}{c}\text { Consanguineous Cases, } \\
\text { n= 48, } \\
\text { \% In Present Study }\end{array}$} & \\
\hline & $\begin{array}{l}\text { No. of } \\
\text { Cases }\end{array}$ & $\begin{array}{c}\% \text { Out of Total } \\
\text { Cases of same } \\
\text { Religion }\end{array}$ & $\begin{array}{l}\text { No. of } \\
\text { Cases }\end{array}$ & $\begin{array}{l}\% \text { Out of Total } \\
\text { Cases of same } \\
\text { Religion }\end{array}$ & No. & $\%$ & No. & $\%$ & Total \\
\hline Hindu & 297 & 64.2 & 165 & 35.7 & 125 & 75.75 & 40 & 24.24 & 165 \\
\hline Muslims & 23 & 60.5 & 15 & 39.4 & 9 & 52.94 & 8 & 47.05 & 17 \\
\hline Total & 320 & 64 & 180 & 36 & 134 & 74.6 & 48 & 26.4 & 182 \\
\hline
\end{tabular}

Table 12 shows A. Nath et $\mathrm{al}^{23}$ in 2004 in their study done in 500 women stated that consanguinity was found in $36 \%$ of the marriages. Muslims had a higher frequency (39.4\%) than Hindus (35.7\%). However, this difference in the frequency was not statistically significant. The findings match with that of present study.

\begin{tabular}{|c|c|c|c|c|c|}
\hline \multirow{3}{*}{$\begin{array}{l}\text { Religion Harlap } \\
\text { S.17 Study }\end{array}$} & \multirow{3}{*}{$\begin{array}{c}\text { Total Births } \\
\text { n=29815, 100\%, No. of } \\
\text { Cases, Harlap S. }{ }^{17} \text { Study }\end{array}$} & \multicolumn{4}{|c|}{ Total Births Studied in the Study, Harlap S.17 Study, $n=29815,100 \%$} \\
\hline & & \multicolumn{3}{|c|}{$\begin{array}{l}\text { Consanguineously Married Cases, } \mathrm{n}=3011 \text {, } \\
\qquad 10.1 \%\end{array}$} & \multirow{2}{*}{$\begin{array}{c}\begin{array}{c}\text { Non-Consanguineous } \\
\text { Married Cases, } \\
\text { N=26804, 89.9\% }\end{array} \\
\text { Total In \% }\end{array}$} \\
\hline & & $\begin{array}{l}\text { Any Distant } \\
\text { Relation, \% }\end{array}$ & $\begin{array}{c}\text { First } \\
\text { Cousin, \% }\end{array}$ & $\begin{array}{l}\text { Uncle- } \\
\text { Niece, \% }\end{array}$ & \\
\hline Total & 29815 cases & 5.3 & 4.6 & 0.3 & 10.1 \\
\hline Muslim & 310 & 39.4 & 33.9 & 0 & 73.2 \\
\hline Christian & 50 & 14.0 & 2.0 & 0 & 16.0 \\
\hline Jewish & 29455 & 4.9 & 4.3 & 0.3 & 9.5 \\
\hline Present study & Total No. of Cases n= 182 & \multicolumn{3}{|c|}{ Consanguineous Cases, $\mathrm{n}=48$} & $\begin{array}{c}\text { Non- Consanguineous } \\
\text { Cases, } n=134\end{array}$ \\
\hline Muslim & 17 & \multicolumn{3}{|c|}{$8(47.05 \%)$} & 9 \\
\hline Hindu & 165 & \multicolumn{3}{|c|}{$40(24.24 \%)$} & 125 \\
\hline Total & 182 & \multicolumn{3}{|c|}{48} & 134 \\
\hline \multicolumn{6}{|c|}{ Table 13} \\
\hline
\end{tabular}

Harlap S, K. Klienhaus. ${ }^{17}$ in 2008 in their study stated that muslims had a higher frequency of consanguineous marriages, i.e. $73.2 \%$ than Hindus. Also consanguinity was most prevalent in muslim community and in parents born in islamic countries. Shown in Table 13 above.

\section{CONCLUSIONS}

1. Incidence of congenital anomalies is $1.16 \%$.

2. Consanguineous marriages and offsprings with congenital defect are found to occur more commonly to parents with primary and secondary education, i.e. Low education status.

3. Consanguineous marriages and offsprings with congenital defect are more to occur more commonly to parents of low socio-economic status, i.e. mothers who are housewives and fathers who are farmers.

4. Frequency of consanguineous marriage is found more in Muslims than Hindus.

\section{REFERENCES}

1. Rudan I, Rudan D, Campbell H, et al. Inbreeding and risk of late onset complex disease. J Med Genet 2003;40(12):925-32.
2. Modell B, Darr A. Science and society: genetic counseling and customary consanguineous marriage. Nat Rev Genet 2002;3:225-9.

3. Fuster V, Colantonio SE. Socioeconomic, demographic, and geographic variables affecting the diverse degrees of consanguineous marriages in Spain. Hum Biol 2004;76(1):1-14.

4. Hussain R, Bittles AH. Sociodemographic correlates of consanguineous marriage in the muslim population of India. J Biosoc Sci 2000;32(4):433-42.

5. Liascovich R, Rittler M, Castilla EE. Consanguinity in South America: demographic aspects. Hum Hered 2001;51(1-2):27-34.

6. Hussain R. Community perceptions of reasons for preference for consanguineous marriages in Pakistan. J Biosoc Sci 1999;31(4):449-61. 
7. Bener A, Hussain R. Consanguineous unions and child health in the state of Qatar. Paediatr Perinat Epidemiol 2006;20(5):372-8.

8. Zaoui S, Biémont C. Frequency of consanguineous unions in the tlemcen area. Sante 2002;12(3):289-95.

9. Simsek S, Ture M, Tugrul B, et al. Consanguineous marriages in Denizli, Turkey. Ann Hum Biol 1999;26(5):489-91.

10. Jurdi R, Saxena PC. The prevalence and correlates of consanguineous marriages in yemen: similarities and contrasts with other Arab countries. J Biosoc Sci 2003;35(1):1-13.

11. Alper $\mathrm{OM}$, Erengin $\mathrm{H}$, Manguoglu $\mathrm{AE}$, et al. Consanguineous marriages in the province of antalya, Turkey. Ann Genet 2004;47(2):129-38.

12. Bittles AH. Endogamy, consanguinity and community genetics. Journal of Genetics 2002;81(3):91-8.

13. Schull WJ. Empirical risks in consanguineous marriages: sex ratio, malformation and viability. Am J Hum Genet 1958;10(3):294-343.

14. Bittles AH, Radha Rama Devi A, Savithri HS, et al. Inbreeding and post-natal mortality in South India: effects on the gene pool. J Genet 1985;64:135-42.

15. Bittles AH. The impact of consanguinity on the Indian population. Indian Journal of Human Genetics 2002;8(2):45-51.

16. Proband. available at en.wikipedia.org/wiki/ Proband.
17. Harlap S, Kleinhaus K, Perrin MC, et al. Consanguinity and birth defects in the Jerusalem perinatal study cohort. Hum Hered 2008;66(3):180-9.

18. Hussain R, Bittles AH. Assessment of association between consanguinity and fertility in Asian populations. J Health Popul Nutr 2004;22(1):1-12.

19. Camilla Stoltenberg, Per Magnus, Rolv Terje Lie, et al. Birth defects and parental consanguinity in norway. American Journal of Epidemiology 1997;145(5):439-48.

20. Khlat $M$, Khoury $M$. Inbreeding and diseases: demographic, genetic and epidemiologic perspectives. Epidiomol rev 1991;13:28-41.

21. Emma Kerkeni, Kamel Monastiri, Besma Saket, et al. Association among education level, occupation status, and consanguinity in tunisia and croatia. Croat Med J 2006;47(4):656-61.

22. Yunis K, Reem El Rafei, Ghina Mumtaz. Consanguinity: perinatal outcomes and prevention- a view from the middle east. International Perspectives 2008;9(2):5964.

23. Nath A, Patil C, Naik VA. Prevalence of consanguineous marriages in a rural community and its effect on pregnancy outcome. Indian Journal of Community Medicine 2004;29(1):p 3.

24. Asha Bai PV, John TJ, Subramanian VR. Reproductive wastage and developmental disorders in relation to consanguinity in south India. Trop Gregor Med 1981;33(3):275-80. 